\section{Degradation of DNA During the Denaturation Step of PCR}

\author{
Andrea Douglas and \\ Bentley Atchison
}

Victorian Institute of Forensic Pathology and Department of Forensic Medicine, Monash University, South Melbourne, 3205 Australia
In many situations it is especially important to maximize the efficiency of a PCR. For example, increased sensitivity decreases the rate of false-negative results when measuring microbial infection and, in a forensic context, limited amounts of crime scene sample often restrict the ability to obtain a PCR DNA profile. (1) Optimization of the various chemical components of the PCR is a standard procedure. ${ }^{(2)}$ However, in establishing the cycle parameters (annealing, extension, and denaturation times), longer periods than theoretically necessary are often used because of the design constraints of a particular PCR instrument. For example, Perkin-Elmer Cetus recommends at least 1-min denaturation times when thick-walled tubes are used in a 480 Thermal Cycler, although, once the sample temperature has reached the effective denaturation temperature, the actual time required for denaturation is relatively short. ${ }^{(3)}$ We found that the synthesis of a 1078-bp fragment from the apolipoprotein AI (apo AI) gene was inefficient when a standard 1-min denaturation time at $94^{\circ} \mathrm{C}$ was used in a 480 Thermal Cycler, but optimization of the denaturation time led to at least a 10-fold increase in synthesis. The poor yield of this fragment of DNA during standard PCR apparently was caused by degradation of the PCR product during the cycling.

\section{MATERIALS AND METHODS}

Amplification of a 1078-bp fragment from the apo AI gene used primers 5'-CTGCAGACATAAATAGGCCC- ${ }^{\prime}$ ' and 5'-AGGCACAGAGAGGAGCTAAA-3' (sequences according to Seilhamer et al. $)^{(4)}$ PCR was performed in a Perkin-Elmer Cetus Thermal Cycler model 480 using $100-\mu l$ reactions in thick-walled PerkinElmer GeneAmp PCR reaction tubes. Reactions contained $200 \mathrm{ng}$ of human DNA, $200 \mathrm{ng}$ of each primer, $200 \mu \mathrm{M}$ each deoxyribonucleoside triphosphate (dNTP), 2.5 units of AmpliTaq (PerkinElmer Cetus), $50 \mathrm{mM} \mathrm{KCl}, 1.5 \mathrm{~mm} \mathrm{MgCl}_{2}$, and $10 \mathrm{~mm}$ Tris- $\mathrm{HCl}(\mathrm{pH} 8.3)$. The PCR consisted of 45 cycles of 1-min annealing at $60^{\circ} \mathrm{C}, 2-\mathrm{min}$ extension at $72^{\circ} \mathrm{C}$, and denaturation at $94^{\circ} \mathrm{C}$ for the specified times. Products were electrophoresed on $5 \%$ polyacrylamide gels and then stained with silver. ${ }^{(5)}$

\section{RESULTS AND DISCUSSION}

In developing a simplified method for sequencing PCR products we found that residual dNTPs from the PCR interfered with subsequent sequencing. ${ }^{(6)}$ This could be overcome by reducing the concentration of the dNTPs in the PCR, but the amplification of some segments of DNA (e.g., apo AI) was inefficient. Degradation of dNTPs is believed to occur during PCR. ${ }^{(7)}$ Therefore, as a test of a simple method for removing the interfering dNTPs, the sample was heated at $94^{\circ} \mathrm{C}$ after completion of the PCR. However, this procedure was unsuccessful because of degradation of the PCR product. This unexpected result suggested that the rate of accumulation of the PCR product during PCR cycling is a balance between the synthesis and degradation of the DNA.

To assess the effect of the denaturation temperature on the stability of the PCR product, six replicate samples were subjected to PCR. All samples produced approximately the same yield of product (Fig. 1A). At the end of the cycling, each of the tubes was heated in the PCR instrument at $94^{\circ} \mathrm{C}$ and then removed from the heating block at different times. As shown in Figure 1B, the PCR product was degraded by heating at $94^{\circ} \mathrm{C}$. Immediate effects were seen with a 30-min incubation and a specific 1078bp length product could not be seen after $60 \mathrm{~min}$ at $94^{\circ} \mathrm{C}$.

To test for the $3^{\prime}$-exonuclease degradation of the PCR product during heating at $94^{\circ} \mathrm{C}$, PCR samples (prepared as in Fig. 1) were extracted with phenol/ chloroform $(50: 50)$ and then washed with diethyl ether. These samples were then heated at $94^{\circ} \mathrm{C}$ as in Figure 1 . Degradation of the phenol-extracted PCR product occurred at a rate similar to that shown in Figure 1 (results not shown).

Denaturation times of $1 \mathrm{~min}$ are recommended when thick-walled PCR reaction tubes are used to allow for the delay in the heating of the samples. ${ }^{(3)}$ Using this parameter, a specific band was produced with the PCR amplification of part of the apo AI gene. However, when the denaturation time was reduced to $30 \mathrm{sec}$, the yield of PCR product was increased $\sim 10$-fold (Fig. 2). Further reduction in the denaturation time to $10 \mathrm{sec}$ resulted in less product than with a 1 -min denaturation.

During the PCR, DNA is subjected to a period of elevated temperature that will vary with the type of instrument used: 


\section{Technical TipsIIIII}

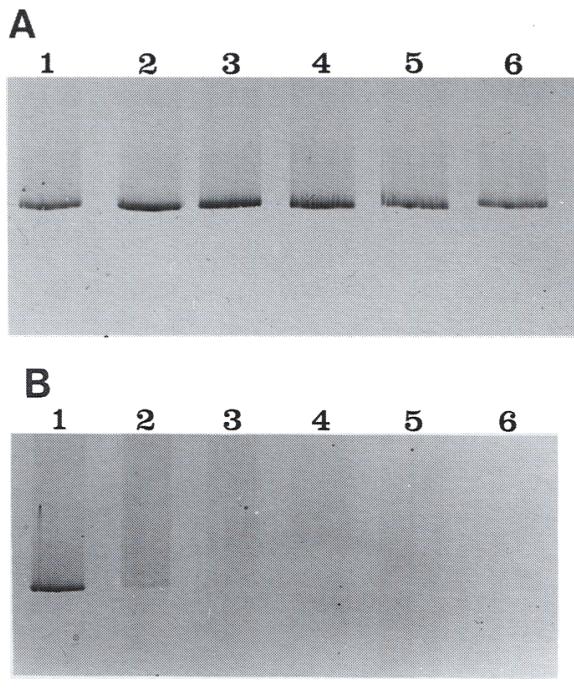

FIGURE 1 Effect of heating a PCR product at $94^{\circ} \mathrm{C}$. (A) A 1078-bp segment of the apo AI gene was amplified in six separate reactions (denaturation time, $1 \mathrm{~min}$ at $94^{\circ} \mathrm{C} / 45$ cycles. (B) Each of the samples shown in $A$ was then held at $94^{\circ} \mathrm{C}$ for $0 \mathrm{~min}$ (lane 1 ), $30 \mathrm{~min}$ (lane 2), $60 \mathrm{~min}$ (lane 3), $90 \mathrm{~min}$ (lane 4), $120 \mathrm{~min}$ (lane 5), and $16 \mathrm{hr}$ (lane 6).

With the newer instruments, this would be 10 min over 40 cycles, compared with $40-60 \mathrm{~min}$ above $90^{\circ} \mathrm{C}$ with a PerkinElmer Cetus 480 Thermal Cycler. In view of the degradation of the PCR product observed in the above experiments, it appears that the overall efficiency of a PCR is a balance between the rate of synthesis of the DNA during the annealing/extension phase and degradation of the DNA at the elevated temperatures required for denaturation. We have used three PCR instruments of the same type (480 Thermal Cycler) and found that the optimum denaturation times are independent of the instrument.

The stoichiometry of the components of a PCR and losses of Taq polymerase

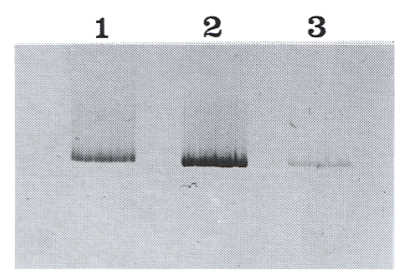

FICURE 2 Effect of denaturation time on the yield of a PCR. PCR of a 1078-bp segment of the apo AI gene was performed as described in the text using 60-sec (lane 1), 30-sec (lane 2), and 10-sec (lane 3) denaturation times at $94^{\circ} \mathrm{C}$. activity during the cycling limits the amount of DNA that can be synthesized. ${ }^{(1)}$ However, degradation of the product during the cycling needs to be considered. As phenol-extracted DNA degraded during heating at $94^{\circ} \mathrm{C}$, it appears that the loss of PCR product is not caused by the 5 '-exonuclease activity of the Taq enzyme: ${ }^{(3)}$ Hydrolysis of the DNA presumably occurs at the temperatures used for denaturation of the DNA. Also, some degradation of the DNA would also occur during the extension phase of the PCR.

The synthesis of the apo AI gene 1078-bp segment appears to be particularly inefficient, but reduction in the denaturation time improved the yield of PCR product. Testing of three other segments of human DNA of varying GC content showed that denaturation times as short as $10 \mathrm{sec}$ were optimal even when using thick-walled tubes (results not shown). Therefore, it is important to consider the denaturation step of a PCR when the yield needs to be maximized.

\section{REFERENCES}

1. Brinkmann, B., S. Rand, and T. Bajanowski. 1992. Forensic identification of urine samples. Int. J. Legal Med. 105: 59-61.

2. Saiki, R. 1989. The design and optimization of the PCR. In PCR technology (ed. H.A. Erlich), pp. 7-16. M. Stockton Press, New York.

3. Sardelli, A.D. 1993. Plateau effect-Understanding PCR limitations. Amplifications 9: 1-5.

4. Seilhamer, J.J., A.A. Protter, P. Frossand, and B. Levy-Wilson. 1984. Isolation and DNA sequence of full-length cDNA and of the entire gene for human apolipoprotein AI-Discovery of a new genetic polymorphism in the apo AI gene. DNA 3: 309317.

5. Allen, R.C., G. Graves, and B. Budowle. 1989. PCR amplification products separated on rehydratable polyacrylamide gels stained with silver. BioTechniques 7: 736-744.

6. Douglas, A.M., A.M. Georgalis, B.A. Atchison. 1993. Direct sequencing of doublestranded PCR products incorporating a chemiluminescent detection procedure. BioTechniques 14: 824-828.

7. Ruano, G., D.E. Brash, and K.K. Kidd. 1991. PCR: The first few cycles. Amplifications 7: 1-4.

Received July 6, 1993; accepted in revised form August 25, 1993. 


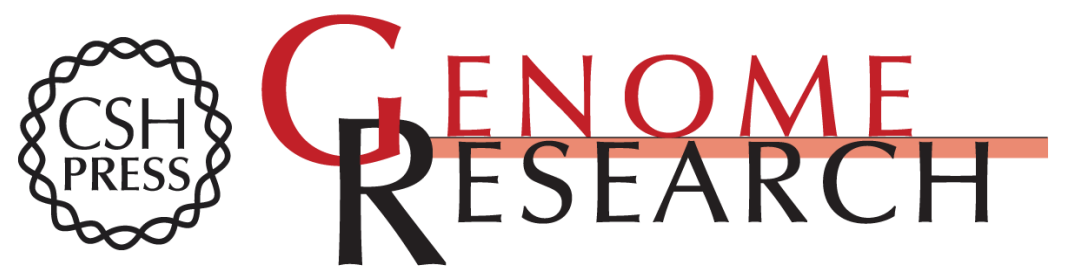

\section{Degradation of DNA during the denaturation step of PCR.}

A Douglas and B Atchison

Genome Res. 1993 3: 133-134

Access the most recent version at doi:10.1101/gr.3.2.133

\section{License}

Email Alerting Receive free email alerts when new articles cite this article - sign up in the box at the Service top right corner of the article or click here.

\section{Affordable, Accurate Sequencing.}

To subscribe to Genome Research go to: https://genome.cshlp.org/subscriptions 